\title{
MANAJEMEN KEUANGAN DAN KEPUASAN KEUANGAN ISTRI PADA KELUARGA DENGAN SUAMI ISTRI BEKERJA
}

\author{
Fitri Apriliana Hakim ${ }^{1 *}$, Euis Sunarti' ${ }^{2}$, Tin Herawati ${ }^{2}$ \\ ${ }^{1}$ Program Studi IImu Keluarga dan Perkembangan Anak, Sekolah Pascasarjana, Institut Pertanian Bogor, \\ Bogor 16680, Indonesia \\ ${ }^{2}$ Staf Pengajar Departemen IImu Keluarga dan Konsumen, Fakultas Ekologi Manusia, Institut Pertanian Bogor, \\ Bogor 16680, Indonesia \\ ")E-mail: fitri.aprilianahakim@gmail.com
}

\begin{abstract}
Abstrak
Penelitian ini bertujuan untuk menganalisis pengaruh karakteristik keluarga dan manajemen keuangan terhadap kepuasan keuangan istri. Desain penelitian yang digunakan adalah cross sectional pada 120 istri dari keluarga dengan suami istri bekerja yang memiliki anak terakhir usia 0-6 tahun. Teknik penarikan contoh menggunakan stratified nonproportional random sampling di Kecamatan Bogor Barat dan Bogor Tengah. Lokasi penelitian ditentukan secara purposive dengan pertimbangan wilayah tersebut merupakan wilayah dengan kepadatan penduduk yang tinggi dengan pendapatan dan tingkat pendidikan yang masih rendah. Hasil penelitian menemukan bahwa satu dari empat istri memiliki manajemen keuangan yang baik dan satu dari sepuluh istri memiliki tingkat kepuasan keuangan tinggi. Manajemen keuangan berhubungan negatif dengan usia istri, besar keluarga, dan lama pernikahan, serta berhubungan positif dengan pendidikan istri, pendapatan per kapita keluarga, dan nilai aset. Manajemen keuangan dan pendidikan istri berpengaruh positif signifikan terhadap kepuasan keuangan istri. Pengetahuan tentang manajemen keuangan perlu diberikan kepada keluarga dengan pendapatan dan pendidikan rendah untuk mencapai kepuasan keuangan.
\end{abstract}

Kata kunci: keluarga suami-istri bekerja, kepuasan keuangan, manajemen keuangan

\section{Financial Management and Wife's Financial Satisfaction of Dual Earner Families}

\begin{abstract}
The purpose of this study was to analyze the influence of family characteristics and financial management on wife financial satisfaction. The research design was a cross sectional of 120 wives from dual earner families whose last child aged 0-6 years old. Samples selected by using nonproportional stratified random sampling technique in Bogor District of West and Central Bogor. The location determined by purposive because represented high density of population with low income and education level. The result of this study found that a quarter wives had good management and one of ten had high level of financial satisfaction. Financial management negatively correlated with wife's age, family size, length of marriage, and positively correlated with wife's education, per capita family income, and values of the asset. Financial management and wife's education had positively significant influenced on wife financial satisfaction. Knowledge of financial management is needed to give to families with low income and low education levels to attain financial satisfaction.
\end{abstract}

Keywords: dual earner family, financial management, financial satisfaction

\section{PENDAHULUAN}

Peningkatan level pendidikan wanita dan semakin luasnya kesempatan kerja membuat semakin banyak wanita yang memasuki lapangan pekerjaan. Data Sakernas menunjuk- kan tingkat partisipasi angkatan kerja wanita mengalami peningkatan yakni dari 52,67 persen pada tahun 2012 menjadi 53,26 persen pada tahun 2013 (BPS, 2014). Hal ini mengindikasikan bahwa kesempatan bekerja untuk wanita terus meningkat sehingga diprediksi jumlah persentase wanita bekerja 
akan mengalami peningkatan pada masa mendatang. Pada tahun 2011, jumlah perempuan yang bekerja di Kota Bogor lebih besar (82.838 jiwa) dibandingkan jumlah perempuan yang tidak bekerja (16.455 jiwa) ${ }^{1}$. Salah satu faktor yang mendorong adalah adanya tuntutan ekonomi yang membuat perempuan harus bekerja di luar rumah. Motif ekonomi yaitu untuk pemenuhan kebutuhan keluarga menjadi alasan utama wanita untuk bekerja sehingga wanita harus membagi waktu antara peran domestik dengan peran publik (Sunarti et al., 2013). Dengan demikian, bekerja dipandang sebagai wujud kontribusi wanita terhadap perekonomian keluarga.

Kontribusi wanita dalam perekonomian keluarga, selain dengan bekerja untuk memenuhi kebutuhan keluarga juga dengan melakukan manajemen keuangan keluarga yang baik guna mencapai tujuan keuangan keluarga. Manajemen keuangan dapat diawali dengan perencanaan keuangan dalam satu bulan. Namun, walaupun perencanaan keuangan keluarga menjadi dasar dalam melakukan manajemen keuangan, hanya sedikit keluarga yang membuat perencanaan keuangan. Perencanaan keuangan dianggap tidak perlu dilakukan dengan asumsi setiap bulan pengeluaran sama atau pendapatan yang diterima tidak menentu. Minat yang mendorong istri membuat perencanaan keuangan keluarga dipengaruhi oleh faktor pendidikan, kepribadian, pendapatan, dan pola pikir (Yohnson, 2004). Hal tersebut menegaskan bahwa semakin tinggi pendidikan yang dimiliki oleh seseorang maka semakin tinggi minatnya untuk membuat perencanaan keuangan keluarga. Tingginya pendidikan juga akan membedakan pengetahuan seseorang tentang keuangan keluarga. Pengetahuan tentang keuangan berhubungan dengan perilaku manajemen keuangan (Titus, Fanslow, \& Hira, 1989). Kurangnya pengetahuan tentang prinsipprinsip pengelolaan keuangan dan masalah keuangan membuat beberapa keluarga tidak mengikuti praktik-praktik keuangan yang telah dianjurkan (Hilgert \& Hogarth, 2003), bahkan sebagian besar keluarga tidak melakukan pencatatan keuangan. Hal ini mengindikasikan perencana-an keuangan yang tidak komprehensif namun berdasarkan kebutuhan sesaat atau insidentil (Joko, 2012).

Tingginya tingkat pengetahuan dan praktik manajemen keuangan berhubungan langsung dengan peningkatan tingkat kepuas-an keuangan (Joo \& Grable, 2004; Loibl \& Hira,
2005). Menurut Joo dan Grable (2004), perilaku keuangan memiliki lebih banyak efek yang signifikan dan langsung pada kepuasan keuangan dari tingkat pendapatan rumah tangga atau faktor demografis lainnya. Namun, studi terkait kepuasan keuangan istri belum banyak dilakukan terutama pada keluarga dengan suami istri bekerja. Oleh karena itu, penting untuk melakukan penelitian tentang pengaruh karakteristik keluarga dan manajemen keuangan keluarga terhadap kepuasan keuangan istri pada keluarga dengan suami istri bekerja. Penelitian ini secara khusus bertujuan untuk: (1) menganalisis karakteristik keluarga, manajemen keuangan, dan kepuasan keuangan istri pada keluarga dengan suami istri bekerja, (2) menganalisis hubungan karakteristik keluarga, manajemen keuangan, dan kepuasan keuangan istri pada keluarga dengan suami istri bekerja, dan (3) menganalisis pengaruh karakteristik keluarga dan manajemen keuangan terhadap kepuasan keuangan istri pada keluarga dengan suami istri bekerja.

\section{METODE}

Penelitian ini menggunakan desain cross sectional dan dilakukan di Kecamatan Bogor Barat (Kelurahan Pasir Jaya, Kelurahan Menteng, dan Kelurahan Cilendek Barat) dan Kecamatan Bogor Tengah (Kelurahan Paledang dan Kelurahan Panaragan). Penentuan lokasi penelitian dengan alasan Kecamatan Bogor Barat termasuk kecamatan dengan jumlah penduduk terbanyak dan Kecamatan Bogor Tengah termasuk kecamatan dengan kepadatan penduduk yang tinggi di Kota Bogor. Pengumpulan data dilakukan pada bulan Februari - April 2014.

Populasi penelitian ini adalah seluruh istri bekerja (bekerja pada sektor informal atau formal) pada keluarga dengan suami istri bekerja yang memiliki anak terakhir usia 0-6 tahun di Kota Bogor. Kerangka contoh dalam penelitian ini adalah istri bekerja (bekerja pada sektor informal atau formal) yang memiliki anak terakhir usia 0-6 tahun pada keluarga dengan suami istri bekerja di Kecamatan Bogor Barat dan Kecamatan Bogor Tengah. Teknik penarikan contoh dilakukan secara stratified nonproporsional random sampling berdasarkan jenis pekerjaan (formal atau informal) dengan contoh sebanyak 120 orang yang masingmasing jenis pekerjaan berjumlah 60 orang.

\footnotetext{
${ }^{1}$ Sumber: http://jabarprov.go.id
} 
Data primer yang dianalisis dalam penelitian ini diperoleh melalui wawancara langsung terhadap responden dengan menggunakan alat bantu kuesioner. Data primer yang dikumpulkan meliputi: (1) karakteristik keluarga, (2) manajemen keuangan yang dilakukan oleh istri yang diukur dengan keusioner hasil modifikasi dari Fitzsimmons et al. (1993), Firdaus \& Sunarti (2009), dan Kumari (2011) yang terdiri atas 20 pernyataan dengan skala jawaban 1 sampai 4 dari tidak pernah sampai selalu, dan (3) kepuasan keuangan yang dirasakan oleh istri diukur dengan kuesioner hasil modifikasi dari Morris \& Lown (1991) dan Loibl \& Hira (2005) yang terdiri atas 10 pernyataan dengan skala jawaban 1 sampai 4 dari tidak puas sampai sangat puas.

Data yang diperoleh selanjutnya diolah dan dianalisis secara deskriptif. Analisis deskriptif digunakan untuk mengidentifikasi karakteristik keluarga (usia istri, pendidikan istri, besar keluarga, pendapatan per kapita, lama pernikahan, dan nilai aset), manajemen keuangan, dan kepuasan keuangan istri. Kategori pengelompokkan untuk manajemen keuangan dibedakan menjadi tiga kategori berdasarkan nilai capaiannya yaitu kurang $(0,00-33,33)$, cukup $(33,34-66,66)$, dan baik $(66,67-100,00)$. Begitu juga dengan kepuasan keuangan istri dibedakan menjadi rendah $(0,00$ $33,33)$, sedang $(33,34-66,66)$, dan tinggi $(66,67-100,00)$. Nilai capaian dari manajemen keuangan dan kepuasan keuangan istri diperoleh dari rumus:

$$
\begin{aligned}
& \mathrm{Y}=\frac{\mathrm{X}-\text { nilai minimum }}{\text { Nilai maksimum }- \text { nilai minimum }} \times 100 \\
& \text { Keterangan: } \\
& \mathrm{Y}=\text { Skor dalam persen } \\
& \mathrm{X}=\text { Skor yang diperoleh untuk setiap contoh }
\end{aligned}
$$

Analisis data juga dilakukan dengan uji hubungan untuk melihat hubungan antara karakteristik keluarga, manajeman keuangan, dan kepuasan keuangan istri pada keluarga dengan suami istri bekerja. Sementara itu, uji regresi linier berganda digunakan untuk menganalisis pengaruh karakteristik keluarga dan manajemen keuangan terhadap kepuasan keuangan istri.

\section{HASIL}

\section{Karakteristik Keluarga}

Hasil penelitian menunjukkan bahwa berdasarkan kelompok pekerjaan istri (formal dan nonformal), terdapat perbedaan yang signifikan pada seluruh subvariabel karakteristik keluarga. Rata-rata besar keluarga istri kelompok informal (4,9 orang) lebih besar dibandingkan kelompok formal (4,2 orang). Sementara itu, rata-rata usia suami $(40,6$ tahun) dan usia istri (36,6 tahun) serta lama pernikahan (13,5 tahun) pada kelompok informal lebih tinggi dibandingkan pada kelompok formal (usia suami $=36,1$ tahun, usia istri $=33,2$ tahun, dan lama pernikahan $=7,8$ tahun).

Selanjutnya, hasil juga menunjukkan bahwa rata-rata pendidikan istri (14,5 tahun) dan suami (13,8 tahun), pendapatan per kapita (Rp1 974 000), dan nilai aset (Rp102.000.000) pada kelompok formal lebih tinggi dibandingkan pada kelompok informal (pendidikan istri $=9,4$ tahun, pendidikan suami $=10,2$ tahun, pendapatan per kapita=Rp907.000, dan nilai aset=Rp29.506.000). Penelitian menemukan bahwa lebih dari separuh $(58,3 \%)$ istri yang bekerja pada jenis pekerjaan informal adalah sebagai wiraswasta; sedangkan pada jenis pekerjaan formal, lebih dari separuh $(51,7 \%)$ istri bekerja sebagai karyawan swasta.

\section{Manajemen Keuangan}

Manajemen adalah suatu proses yang berbeda terdiri atas planning, organizing, actuating, dan controlling yang dilakukan untuk mencapai tujuan yang ditentukan dengan manusia dan sumberdaya lainnya (Herujito, 2001). Manajemen keuangan keluarga adalah mengelola atau mengatur keuangan keluarga untuk memenuhi kebutuhan hidup keluarga sehari-hari. Manajemen keuangan merupakan serangkaian tugas dalam memaksimalkan perolehan bunga dan meminimalisir biaya, serta memastikan ketersediaan dana untuk kebutuhan sehari-hari, pengeluaran rumah tangga, kondisi darurat, tabungan maupun kesempatan untuk investasi (Garman \& Forgue, 2000).

Hasil penelitian (Tabel 1) menunjukkan bahwa manajemen keuangan yang dicapai oleh keseluruhan istri (baik yang bekerja pada sektor formal maupun informal) memiliki rata-rata 50,1 . Analisis indeks capaian manajemen keuangan menunjukkan bahwa capaian tertinggi manajemen keuangan yang dilakukan istri adalah dalam hal membicarakan masalah keuangan dengan suami $(77,5)$ yang merupakan dimensi pengontrolan, dan membayar tanggungan bulanan dari tabungan saat ini $(76,1)$ yang merupakan dimensi pelaksanaan. 
Hasil yang tersaji pada Tabel 1 menunjukkan bahwa pada dimensi perencanaan, tidak ada satu pun dimensi yang capaiannya mencapai 66,67. Artinya seluruh istri pada penelitian ini, baik yang bekerja pada sektor formal maupun informal, belum mempunyai perencanaan keuangan yang baik. Pembuatan perencanaan penggunaan uang dalam satu bulan, perencanaan dan penulisan tujuan keuangan, penghitungan perkiraan biaya hidup, serta perencanaan untuk mencapai tujuan keuangan yang ingin dicapai belum dilakukan dengan baik oleh para istri dari keluarga dengan suami istri bekerja pada penelitian ini.

Hasil lain juga menunjukkan bahwa pada dimensi pengorganisasian, belum ada satu aspek pun yang sudah dilakukan dengan baik oleh para istri yang ditunjukkan dari capaian indeks yang belum mencapai 66,67 (Tabel 1). Istri sebenarnya sudah melakukan pemisahan uang sesuai dengan kegunaannya serta penyimpanan bukti pembayaran untuk pembelian yang besar dengan cukup baik. Namun, mencatat seluruh pendapatan dan pengeluaran keuangan serta menetapkan standar biaya maksimal dalam pengalokasian pengeluaran masih sangat jarang dilakukan.

Berbeda halnya dengan dimensi perencanaan dan pengorganisasian, pada dimensi pelaksanaan terdapat aspek yang sudah dilakukan istri dengan baik yaitu berusaha menabung (Tabel 1). Meskipun seringkali tabungan tersebut digunakan untuk membayar tanggungan bulanan yang tidak bisa dibayar dari pendapatan yang diperoleh. Secara keseluruhan, pada dimensi pelaksanaan keuangan, para istri juga belum menunjukkan kemampuan pengelolaan keuangan yang baik. Beberapa aspek yang bisa dicermati adalah capaian yang tinggi pada pembuatan keputusan keuangan tanpa berpikir panjang. Hal ini menunjukkan bahwa istri tidak memiliki perencanaan keuangan yang baik sehingga harus melakukan keputusan keuangan yang tidak direncanakan. Temuan ini juga ditunjang dari rendahnya capaian istri dalam merujuk rencana keuangan sebelum membeli sesuatu (44,7). Temuan-temuan tersebut mengindikasikan pelaksanaan keuangan yang masih belum baik dilakukan istri.

Selanjutnya pada Tabel 1 juga dapat dilihat capaian istri dalam manajemen keuangan untuk dimensi pengontrolan. Hasil penelitian ini menemukan bahwa terdapat satu aspek pada dimensi pengontrolan keuangan yang sudah dilakukan dengan baik oleh istri, yaitu pada aspek membicarakan permasalahan keuangan dengan suami. Sementara itu, pada aspek melakukan evaluasi keuangan secara teratur, rutin, dan menyeluruh serta mem-bandingkan penerimaan dengan pengeluaran masih jarang dilakukan istri. Hal tersebut membuat secara keseluruhan pengontrolan keuangan yang dilakukan istri belum baik.

Tabel 1 Indeks capaian manajemen keuangan istri atas setiap pernyataan

\begin{tabular}{|c|c|}
\hline Pernyataan & $\begin{array}{l}\text { Indeks } \\
\text { capaian }(0- \\
100) \\
\end{array}$ \\
\hline Dimensi perencanaan & 44,7 \\
\hline $\begin{array}{l}\text { 1. Membuat perencanaan } \\
\text { penggunaan uang dalam satu } \\
\text { bulan }\end{array}$ & 45,6 \\
\hline $\begin{array}{l}\text { 2. Membuat rencana untuk tujuan } \\
\text { keuangan masa depan }\end{array}$ & 49,7 \\
\hline $\begin{array}{l}\text { 3. Menghitung perkiraan biaya } \\
\text { hidup sehari-hari }\end{array}$ & 53,6 \\
\hline 4. Menuliskan tujuan keuangan & 32,8 \\
\hline $\begin{array}{l}\text { 5. Membuat rencana untuk } \\
\text { mencapai tujuan keuangan yang } \\
\text { ingin dicapai }\end{array}$ & 41,7 \\
\hline Dimensi pengorganisasian & 43,1 \\
\hline 1. Mencatat seluruh pendapatan & 34,2 \\
\hline $\begin{array}{l}\text { 2. Menuliskan pengeluaran } \\
\text { keuangan }\end{array}$ & 34,2 \\
\hline $\begin{array}{l}\text { 3. Menetapkan standar biaya } \\
\text { maksimal dalam pengalokasian } \\
\text { pengeluaran }\end{array}$ & 37,5 \\
\hline $\begin{array}{l}\text { 4. Memisahkan uang sesuai } \\
\text { dengan kegunaannya }\end{array}$ & 57,8 \\
\hline $\begin{array}{l}\text { 5. Menyimpan bukti pembayaran } \\
\text { untuk pembelian yang besar }\end{array}$ & 51,7 \\
\hline Dimensi pelaksanaan & 59,5 \\
\hline $\begin{array}{l}\text { 1. Melakukan pengeluaran sesuai } \\
\text { dengan yang telah dianggarkan }\end{array}$ & 43,1 \\
\hline $\begin{array}{l}\text { 2. Merujuk pada rencana sebelum } \\
\text { membeli sesuatu }\end{array}$ & 44,7 \\
\hline $\begin{array}{l}\text { 3. Membayar tanggungan bulanan } \\
\text { dari tabungan saat ini }\end{array}$ & 76,1 \\
\hline $\begin{array}{l}\text { 4. Membuat keputusan keuangan } \\
\text { tanpa berfikir panjang }\end{array}$ & 68,9 \\
\hline $\begin{array}{l}\text { 5. Melakukan pembelian tak } \\
\text { terencana }\end{array}$ & 56,4 \\
\hline 6. Berusaha menabung & 68,1 \\
\hline Dimensi pengontrolan & 51,5 \\
\hline $\begin{array}{l}\text { 1. Melakukan evaluasi pengeluaran } \\
\text { secara teratur }\end{array}$ & 40,8 \\
\hline $\begin{array}{l}\text { 2. Mengevaluasi pengeluaran } \\
\text { secara rutin dan menyeluruh }\end{array}$ & 36,4 \\
\hline $\begin{array}{l}\text { 3. Membandingkan penerimaan } \\
\text { dan pengeluaran }\end{array}$ & 51,4 \\
\hline $\begin{array}{l}\text { 4. Membicarakan masalah } \\
\text { keuangan dengan suami }\end{array}$ & 77,5 \\
\hline Manajemen keuangan total & 50,1 \\
\hline
\end{tabular}


Secara keseluruhan seperti yang tersaji pada Tabel 1 , rata-rata capaian tertinggi $(59,5)$ adalah dalam hal pelaksanaan, kemudian dalam hal pengontrolan $(51,5)$. Sementara itu, dalam hal perencanaan dan pengorganisasian rata-rata sebesar 44,7 dan 43,1. Hasil ini menegaskan bahwa sebagian istri pada penelitian ini, yang semuanya merupakan istri dari keluarga dengan suami dan istri bekerja, belum melakukan manajemen keuangan dengan baik.

Analisis capaian rata-rata manajemen keuangan istri juga ditunjang dengan analisis pengkategorian istri berdasarkan tingkatan manajemen keuangan seperti yang tersaji pada Tabel 2. Data yang tersaji pada Tabel 2 menunjukkan bahwa hanya satu dari empat istri $(25,0 \%)$ yang telah melakukan manajemen keuangan dengan baik. Sementara itu, sekitar dua dari empat istri $(48,3 \%)$ melakukan manajemen keuangan dengan cukup baik dan masih ada sekitar satu dari empat istri $(26,7 \%)$ yang masih kurang dalam melakukan praktik manajemen keuangan.

\section{Kepuasan Keuangan Istri}

Kepuasan keuangan adalah persepsi subjektif individu dari kecukupan sumber daya keuangan sendiri. Kepuasan keuangan telah lama diakui sebagai komponen kesejahteraan dan telah mendapat perhatian dalam studi tentang kesehatan terkait stres seperti tekanan keuangan dan isu-isu manajemen risiko (Roob \& Woodyard, 2011). Penentu kepuasan keuangan meliputi faktor demografi seperti pendapatan, pendidikan, etnis, dan usia, serta stres keuangan, pengetahuan keuangan, sikap dan perilaku keuangan. Tingginya tingkat pengetahuan dan praktik manajemen keuangan juga berhubungan langsung dengan peningkatan tingkat kepuasan keuangan (Joo \& Grable, 2004; Loibl \& Hira, 2005). Dalam penelitian ini kepuaasan keuangan istri akan dianalisis lebih lanjut kaitannya dengan manajemen keuangan yang dilakukan istri.

Tabel 1 Sebaran istri berdasarkan kategori capaian manajemen keuangan

\begin{tabular}{lrr}
\hline $\begin{array}{l}\text { Kategori capaian manajemen } \\
\text { keuangan }\end{array}$ & Jumlah & Persen \\
\hline Kurang $(0,0-33,3)$ & 32 & 26,7 \\
Cukup $(33,4-66,6)$ & 58 & 48,3 \\
Baik $(66,7-100,0)$ & 30 & 25,0 \\
\hline Total & 120 & 100,0 \\
\hline
\end{tabular}

Hasil yang tersaji pada Tabel 3 menunjukkan kepuasan keuangan istri secara keseluruhan memiliki rata-rata capaian 44,8. Berdasarkan kategori yang digunakan dalam penelitian ini, capaian tersebut menunjukkan bahwa rata-rata istri baru merasa cukup puas dengan kondisi keuangannya saat ini. Apabila dianalisis untuk setiap pernyataan, rata-rata capaian kepuasan keuangan istri tertinggi $(45,6 \%)$ adalah dalam hal kemampuan membayar hutang, sedangkan persentase terendah $(12,7 \%)$ adalah dalam hal perencanaan warisan. Sementara itu, dalam hal pendapatan yang diterima, kemampuan keuangan keluarga untuk menangani keadaan darurat atau biaya tak terduga yang besar, jumlah uang tunai yang dimiliki keluarga, tingkat atau jumlah tabungan yang dimiliki keluarga, uang untuk kebutuhan mendatang keluarga atau jangka panjang, cara penggunaan uang, kemampuan dalam membuat keputusan investasi, dan kemampuan dalam mengendalikan siatuasi keuangan masih memiliki rata-rata capaian berkisar 29,4 sampai dengan 39,0. Temuan ini menunjukkan bahwa sebagian besar aspek kepuasan keuangan masih rendah tingkat kepuasan yang dirasakan istri.

Tabel 3 Indeks capaian kepuasan keuangan istri atas setiap pernyataan

\begin{tabular}{lc}
\hline Pernyataan & Persentase \\
\hline $\begin{array}{l}\text { Pendapatan yang diterima } \\
\text { Kemampuan keuangan keluarga } \\
\text { untuk menangani keadaan } \\
\text { darurat/biaya tak terduga yang }\end{array}$ & 37,5 \\
besar & \\
Jumlah uang tunai yang dimiliki & \\
oleh keluarga & 35,8 \\
$\begin{array}{l}\text { Tingkat/jumlah tabungan yang } \\
\text { dimiliki keluarga }\end{array}$ & 29,4 \\
$\begin{array}{l}\text { Uang untuk kebutuhan } \\
\text { mendatang keluarga/jangka }\end{array}$ & 29,8 \\
panjang & \\
$\begin{array}{l}\text { Cara penggunaan uang yang } \\
\text { telah dilakukan }\end{array}$ & 39,0 \\
$\begin{array}{l}\text { Kemampuan dalam membuat } \\
\text { keputusan investasi dengan uang } \\
\text { yang disimpan }\end{array}$ & 32,9 \\
$\begin{array}{l}\text { Sejauh mana telah mampu } \\
\text { mengendalikan situasi keuangan }\end{array}$ & 39,0 \\
$\begin{array}{l}\text { Perencanaan warisan yang telah } \\
\text { dilakukan }\end{array}$ & 12,7 \\
$\begin{array}{l}\text { Kemampuan dalam membayar } \\
\text { hutang (termasuk tagihan kartu } \\
\text { kredit) }\end{array}$ & 45,6 \\
\hline $\begin{array}{l}\text { Rata-rata kepuasan keuangan } \\
\text { istri }\end{array}$ & 44,8 \\
\hline
\end{tabular}


Tabel 2 Sebaran contoh berdasarkan kategori tingkat kepuasan keuangan istri

\begin{tabular}{lrr}
\hline $\begin{array}{c}\text { Kategori tingkat kepuasan } \\
\text { keuangan istri }\end{array}$ & $\mathrm{n}$ & \multicolumn{1}{c}{$\%$} \\
\hline Rendah $(0,0-33,3)$ & 30 & 25,0 \\
Sedang $(33,4-66,6)$ & 79 & 65,8 \\
Tinggi $(66,7-100,0)$ & 11 & 9,2 \\
\hline Total & 120 & 100,0 \\
\hline
\end{tabular}

Selanjutnya pada Tabel 4, analisis kepuasan keuangan istri berdasarkan tingkatan kepuasan yang digunakan dalam penelitian ini menunjukkan bahwa sekitar tujuh dari sepuluh istri $(65,8 \%)$ memiliki kepuasan keuangan pada kategori sedang. Artinya sebagian besar istri baru merasa cukup puas dengan kondisi keuangannya saat ini. Sementara itu, hasil penelitian juga menemukan bahwa sekitar dua dari sepuluh istri $(25,0 \%)$ memiliki kepuasan keuangan pada kategori rendah, dan hanya satu dari sepuluh istri $(9,2 \%)$ yang memiliki kepuasan keuangan pada kategori tinggi. Temuan ini menegaskan hasil rata-rata capaian indeks kepuasan keuangan istri bahwa sebagian besar istri (sembilan dari sepuluh istri) belum merasakan kepuasan yang tinggi terhadap kondisi keuangannya saat ini.

\section{Hubungan Antarpeubah Penelitian}

Hasil analisis hubungan antara karakterisrik keluarga, manajemen keuangan, dan kepuasan keuangan istri (Tabel 5) menunjukkan bahwa manajemen keuangan berhubungan negatif dengan usia istri, besar keluarga, dan lama pernikahan. Hal ini berarti semakin tua usia istri, semakin besar jumlah anggota keluarga, dan semakin lama usia pernikahan, maka semakin rendah manajemen keuangan yang dilakukan istri. Sebaliknya, pendidikan istri, pendapatan per kapita keluarga, dan nilai aset berhubungan positif dengan manajemen keuangan. Temuan ini berarti bahwa semakin tinggi pendidikan istri, semakin tinggi pendapatan per kapita keluarga, dan semakin tinggi nilai aset yang dimiliki keluarga maka semakin baik manajemen keuangan yang dilakukan istri pada keluarga dengan suami istri bekerja.

Sementara itu, hasil lain yang juga disajikan pada Tabel 5 menemukan bahwa kepuasan keuangan istri berhubungan positif dengan pendidikan istri, pendapatan per kapita keluarga, nilai aset keluarga, dan manajemen keuangan. Hasil ini mengindikasikan bahwa semakin tinggi tingkat pendidikan istri, semakin tinggi pendapatan per kapita per bulan keluarga, semakin besar nilai aset keluarga, dan semakin baik manajemen keuangan maka semakin tinggi kepuasan keuangan yang dirasakan istri pada keluarga dengan suami istri bekerja.

\section{Pengaruh Karakteristik Keluarga dan Manajemen Keuangan terhadap Kepuasan Keuangan}

Hasil analisis (Tabel 6) menunjukkan bahwa model regresi yang dibangun penelitian ini untuk menganalisis pengaruh karakteristik keluarga dan manajemen keuangan terhadap kepuasan keuangan istri pada keluarga dengan suami istri bekerja memiliki nilai Adjusted $\mathrm{R}$ Square sebesar 0,347. Artinya variabel karakteristik keluarga dan manajemen keuangan istri dapat menjelaskan 34,7 persen pengaruh kepuasan keuangan yang dirasakan istri pada keluarga dengan suami istri bekerja. Hasil uji regresi pada Tabel 6 menunjukkan bahwa pendidikan istri dan manajemen keuangan adalah variabel yang memberikan pengaruh signifikan terhadap kepuasan keuangan istri. Peningkatan pendidikan istri selama satu tahun akan berpengaruh terhadap peningkatan kepuasan keuangan istri pada keluarga dengan suami istri bekerja sebesar 1,422 poin. Sementara itu, peningkatan manajemen keuangan yang dilakukan istri sebesar satu poin juga akan berpengaruh terhadap peningkatan kepuasan keuangan istri pada keluarga dengan suami istri bekerja sebesar 0,262 poin.

Tabel 5 Koefisien korelasi antara karakteristik keluarga, manajemen keuangan, dan kepuasan keuangan istri

\begin{tabular}{|c|c|c|c|c|c|c|c|c|}
\hline Variabel & $\mathrm{X} 1$ & $\mathrm{X} 2$ & $\mathrm{X} 3$ & $\mathrm{X} 4$ & $\times 5$ & $\mathrm{X} 6$ & $\mathrm{X} 7$ & $\mathrm{X} 8$ \\
\hline Usia istri (X1) & -1 & & & & & & & \\
\hline Pendidikan istri (X2) & $-0,110$ & 1 & & & & & & \\
\hline Besar keluarga (X3) & $-0,473^{\star *}$ & $0,289^{*}$ & 1 & & & & & \\
\hline Pendapatan per kapita (X4) & $-0,010$ & $0,482^{* *}$ & $0,209^{*}$ & 1 & & & & \\
\hline Lama pernikahan (X5) & $-0,765^{\star *}$ & $0,388^{\star *}$ & $0,624^{\star \star}$ & 0,147 & -1 & & & \\
\hline Nilai aset $(X 6)$ & $-0,253^{* *}$ & $0,452^{* *}$ & 0,064 & $0,547^{* *}$ & $-0,092$ & 1 & & \\
\hline Manajemen keuangan (X7) & $-0,207^{*}$ & $0,443^{* *}$ &, $362^{\star \star}$ & $0,333^{\star *}$ & $-0,296^{* *}$ & $0,179^{*}$ & 1 & \\
\hline Kepuasan keuangan $(\mathrm{X} 8)$ & $-0,030$ & $0,525^{\star *}$ & 0,115 & $0,402^{\star *}$ & $-0,126$ & $0,398^{\star *}$ & $0,455^{\star \star}$ & 1 \\
\hline
\end{tabular}

Keterangan: * Signifikan pada $p<0,05,{ }^{\star \star}$ Signifikan pada $p<0,01$ 
Tabel 6 Koefisien regresi pengaruh karakteristik keluarga dan manajemen keuangan terhadap kepuasan keuangan istri

\begin{tabular}{|c|c|c|c|}
\hline \multirow{2}{*}{ Variabel } & \multicolumn{3}{|c|}{ Kepuasan keuangan istri } \\
\hline & $\mathrm{B}$ & $\beta$ & Sig. \\
\hline Konstanta & 2,230 & - & $0,849^{* *}$ \\
\hline Usia istri (tahun) & 0,190 & 0,071 & $0,567^{\star *}$ \\
\hline $\begin{array}{l}\text { Pendidikan istri } \\
\text { (tahun) }\end{array}$ & 1,422 & 0,311 & $0,003^{* *}$ \\
\hline $\begin{array}{l}\text { Besar keluarga } \\
\text { (orang) }\end{array}$ & 0,971 & 0,068 & $0,493^{* *}$ \\
\hline $\begin{array}{l}\text { Pendapatan per } \\
\text { kapita (Rp/bulan) }\end{array}$ & $8,936 \mathrm{E}-7$ & 0,094 & $0,328^{* *}$ \\
\hline $\begin{array}{l}\text { Lama pernikahan } \\
\text { (tahun) }\end{array}$ & $-0,033$ & $-0,012$ & $0,931^{* *}$ \\
\hline Nilai aset (Rp) & $1,58 \mathrm{E}-8$ & 0,132 & $0,187^{\star *}$ \\
\hline $\begin{array}{l}\text { Manajemen } \\
\text { keuangan (indeks) }\end{array}$ & 0,262 & 0,298 & $0,001^{* *}$ \\
\hline $\mathrm{F}$ & & & $10,014^{* *}$ \\
\hline Sig. & & & $0,000^{* *}$ \\
\hline $\mathrm{R}^{2}$ & & & $0,385^{\star *}$ \\
\hline Adjusted R Square & & & $0,347^{* *}$ \\
\hline
\end{tabular}

\section{Keterangan:}

$\mathrm{B}=$ Tidak terstandardisasi

$\beta=$ Terstandardisasi

** Signifikan pada $\mathrm{p}<0,01$

\section{PEMBAHASAN}

Hasil penelitian ini menunjukkan bahwa kepuasan keuangan dipengaruhi oleh manajemen keuangan dan pendidikan istri. Sementara itu, penelitian ini juga menemukan bahwa manajemen keuangan berhubungan positif dengan pendidikan istri, pendapatan per kapita keluarga, dan nilai aset keluarga, namun berhubungan negatif dengan usia istri, besar keluarga, dan lama pernikahan. Hasil penelitian Firdaus \& Sunarti (2009) menyatakan bahwa pendidikan berhubungan positif dengan manajemen keuangan keluarga. Namun dalam penelitian ini, tidak hanya pendidikan yang berhubungan dengan manajemen keuangan tetapi pendapatan per kapita dan nilai aset juga berhubungan positif dengan manajemen keuangan yang dilakukan.

Penelitian ini juga menemukan bahwa hanya satu dari empat istri pada keluarga dengan suami istri bekerja $(25,0 \%)$ yang melakukan manajemen keuangan dengan baik. Hal ini dapat terjadi karena dalam penelitian ini hanya 2,5 persen istri saja yang memiliki lama pendidikan lebih dari 16 tahun. Iskandar (2008) mengatakan bahwa faktor yang memengaruhi proses manajemen salah satunya adalah tingkat pendidikan. Tingkat pendidikan yang rendah akan menyebabkan kurangnya pengetahuan tentang prinsip-prinsip pengelolaan keuangan dan masalah keuangan sehingga beberapa keluarga tidak mengikuti praktikpraktik keuangan yang dianjurkan (Hilgert \& Hogarth, 2003).

Hasil penelitian menunjukkan bahwa hanya satu dari sepuluh istri $(9,0 \%)$ yang memiliki tingkat kepuasan keuangan yang tinggi, sedangkan satu dari empat istri $(25,0 \%)$ mempunyai tingkat kepuasan keuangannya terkategori rendah. Kepuasan keuangan istri dipengaruhi secara signifikan oleh manajemen keuangan dan pendidikan istri. Hasil dalam penelitian ini menegaskan bahwa peningkatan kepuasan keuangan istri sejalan dengan peningkatan manajemen keuangan yang dilakukan istri dan tingkat pendidikan istri. Hal ini serupa dengan hasil penelitian sebelumnya oleh Joo \& Grable (2004) juga Loibl \& Hira (2005) yang menyebutkan bahwa peningkatan tingkat kepuasan keuangan berhubungan dengan tingginya tingkat pengetahuan dan praktik manajemen keuangan.

Sementara itu, hasil analisis juga menunjukkan bahwa pendapatan per kapita berhubungan positif dengan nilai aset. Hasil tersebut menggambarkan bahwa semakin tinggi pendapatan per kapita maka semakin tinggi nilai aset yang dimiliki. Dalam penelitian ini, rata-rata pendapatan per kapita keluarga dalam penelitian ini adalah sebesar Rp1.440.000,00 per bulan dan satu dari empat istri $(26,7 \%)$ memiliki aset kurang dari 10 juta rupiah. Pendapatan yang diperoleh memberikan efek positif terhadap kepemilikan aset keuangan (Xiao, 1996).

Hasil uji hubungan menunjukkan bahwa manajemen keuangan berhubungan positif dengan pendapatan per kapita dan nilai aset. Temuan tersebut mengindikasikan bahwa semakin tinggi pendapatan per kapita keluarga maka semakin tinggi nilai aset dan semakin baik manajemen keuangan yang dilakukan. Hasil penelitian ini dapat didukung oleh hasil penelitian Simanjuntak (2010) yang menyatakan bahwa praktik manajemen sumberdaya keuangan tergolong rendah pada keluarga miskin karena pendapatan yang dimiliki tidak teratur. Selanjutnya, manajemen keuangan berpengaruh terhadap kepuasan keuangan istri sehingga secara tidak langsung pendapatan per kapita dan nilai aset memiliki pengaruh terhadap kepuasan keuangan istri. Parrotta \& Johnson (1998) mengatakan semakin tinggi pendapatan dan penggunaan praktik keuangan maka semakin tinggi tingkat kepuasan terhadap status keuangan. 
Hasil lain penelitian ini menemukan bahwa besar keluarga, usia istri, dan lama pernikahan berhubungan negatif dengan manajemen keuangan. Hasil tersebut menggambarkan bahwa semakin besar jumlah anggota keluarga maka semakin rendah manajemen keuangan yang dilakukan. Sementara itu, ketika manajemen yang dilakukan rendah maka kepuasan keuangan yang dirasakan juga rendah. Hasil penelitian Firdaus \& Sunarti (2009) menyebutkan bahwa besar keluarga berhubungan negatif dengan kesejahteraan keluarga. Hal ini menunjukkan bahwa semakin banyak anggota keluarga maka semakin rendah kesejahteraan keluarganya. Usia istri dan lama pernikahan juga memiliki hubungan negatif signifikan dengan manajemen keuangan, dan usia istri saling berhubungan dengan lama pernikahan. Hal tersebut mengindikasikan bahwa semakin tua istri, semakin lama usia pernikahannya maka semakin rendah manajemen keuangan yang dilakukan. Sunarti et al. (2013) mengatakan keluarga baru menikah mencoba untuk menabung, namun mereka tetap memutuskan untuk menabung ketika mendekati masa tua.

Selanjutnya, penelitian ini juga menemukan bahwa dalam hal pendapatan yang diterima, jumlah tabungan, dan keputusan investasi, rata-rata capaian kepuasan istri berkisar 29,4 sampai dengan 37,5. Namun, dalam hal berusaha menabung, rata-rata capaian istri sebesar 68,1. Menurut Hong et al. (2002), tingkat tabungan secara positif berhubungan dengan pendapatan rumah tangga, jumlah aset likuid, dan jumlah penerimaan dalam rumah tangga. Faktor ekonomi memiliki hubungan yang lebih kuat dengan perilaku manabung jika dibandingkan dengan faktor sosiologis dan psikologis. Secara khusus, usia dan skor perilaku keuangan secara signifikan terkait dengan kemungkinan memiliki rekening tabungan sedangkan pendapatan, kekayaan bersih, dan pendidikan secara signifikan terkait dengan kemungkinan memiliki rekening tabungan dan investasi (Gutter et al., 2012).

Secara umum, penelitian ini menegaskan betapa pentingnya manajemen keuangan yang baik dalam meningkatkan kepuasan keuangan istri. Penelitian ini yang berfokus pada istri dari keluarga dengan suami istri bekerja juga menemukan hasil yang konsisten, bahwasanya manajemen keuangan yang baik mulai dari perencanaan, pengorganisasia, pelaksanaan, hingga pengontrolan keuangan yang baik akan berpengaruh terhadap peningkatan kepuasan istri terhadap keadaan keuangan yang dimilikinya.

\section{SIMPULAN DAN SARAN}

Manajemen keuangan secara signifikan menurun bila dengan usia istri, besar keluarga, dan lama pernikahan bertambah. Sementara itu, pendidikan istri, pendapatan per kapita keluarga, dan nilai aset keluarga yang semakin bertambah berhubungan signifikan dengan semakin baiknya manajemen keuangan dan kepuasan keuangan istri. Manajemen keuangan yang semakin baik berhubungan signifikan dengan semakin puasnya istri terhadap kondisi keuangannya. Manajemen keuangan dan pendidikan istri memiliki pengaruh yang positif terhadap kepuasan keuangan istri. Dengan demikian, peningkatan kepuasan keuangan istri akan sejalan dengan peningkatan manajemen keuangan yang dilakukan istri dan tingkat pendidikan istri.

Adapun saran bagi pemerintah, LSM, dan perguruan tinggi agar memberikan penyuluhan tentang manajemen keuangan keluarga terutama kepada keluarga dengan tingkat pendidikan rendah, pendapatan keluarga yang rendah, serta jumlah anggota keluarga yang besar, sehingga dapat meningkatkan kepuasan keuangan yang dirasakan keluarga. Pada penelitian selanjutnya diharapkan kepuasan keuangan tidak hanya diteliti berdasarkan persepsi istri, namun kepuasan keuangan juga dilihat dari persepsi suami. Selain itu, lokasi pada penelitian ini mengambil daerah perkotaan. Pada penelitian selanjutnya diharapkan dapat menambahkan daerah pedesaan sehingga dapat melakukan uji beda berdasarkan lokasi tempat tinggal.

\section{DAFTAR PUSTAKA}

[BPS] Badan Pusat Statistik. (2014). Keadaan Ketenagakerjaan. Jakarta, ID: Badan Pusat Statistik.

Firdaus, \& Sunarti, E. (2009). Hubungan antara tekanan ekonomi dan mekanisme koping dengan kesejahteraan keluarga wanita pemetik teh. Jur. IIm. Kel. \& Kons., 2(1), 21-31.

Fitzsimmons, V. S., Hira, T. K., Bauer, J. W., \& Hafstrom, J. L. (1993). Financial management: development of scales. Journal of Family and Economic Issues, 14(3), 257-274.

Garman, E. T., \& Forgue R. E. (2000). Personal finance, sixth edition. Boston, US: Houghton Mifflin Publishing.

Gutter, M. S., Hayhoe, C. R., DeVaney, S. A., Kim, J., Bowen, C. F., Chaeng, M., Cho,... 
Dorman, R. (2012). Exploring the relationship of economic, sociological, and psychological factors to savings behavior of low-to moderate-income households. Family and Consumer Sciences Research Journal, 41(1), 86-101.

Herujito, Y. M. (2001). Dasar-dasar manajemen. Jakarta, ID: Grasindo.

Hilgert, M. A., \& Hogarth, J. M. (2003, July). Household financial management: The connection between knowledge and behavior. Federal Reserve Bulletin.

Hong, G., Sung, J., \& Kim, S. (2002). Saving behavior among Korean Households. Family and Consumer Sciences Research Journal, 30(4), 437-462.

Iskandar, A. (2008). Analisis praktik manajemen sumberdaya keluarga dan dampaknya terhadap kesejahteraan keluarga di Kabupaten dan Kota Bogor. Jurnal Transdisiplin Sosiologis, Komunikasi, dan Ekologi Manusia, 2(1), 81-98.

Joko, F. A. (2012, Januari). Pola konsumsi, investasi, dan proteksi sebagai indikator perencanaan keuangan keluarga (studi pada masyarakat Kabupaten Sidoarjo). Media Mahardhika, 10(2),44-66.

Joo, S., \& Grable, J. E. (2004). An exploratory framework of the determinants of financial satisfaction. Journal of Family and Economic Issues, 25, 25-50.

Kumari, K. K. (2011). Marital adjustment and family resource management of working women among different income groups. International Referred Research Journal, $3(27)$.

Loibl, C., \& Hira, T. K. (2005). Self-directed financial learning and financial satisfaction. Financial Counseling and Planning, 16(1), 11-21.
Morris, S. L., \& Lown, J. M. (1991). Personal finance education in relation to financial satisfaction, confidence, and practices. Journal of Consumer Education, 9, 34-38.

Parrotta, J. L., \& Johnson, P. J. (1998). The impact of financial attitudes and knowledge on financial management and satisfaction of recently married individuals. Journal of Financial Counseling and Planning, 9(2), 59-75.

Robb, C. A., \& Woodyard, A. S. (2011). Financial knowledge and best practice behavior. Journal of Financial Counseling and Planning, 22(1), 60-70.

Simanjuntak, M. (2010). Faktor-faktor yang memengaruhi kesejahteraan keluarga dan prestasi belajar anak pada keluarga penerima program keluarga harapan (PKH) (tesis). Sekolah Pascasarjana, Institut Pertanian Bogor, Bogor.

Sunarti, E., Kholifah, I., Vidiastuti, F., Kharisma, N., Rochimah, N., \& Herawati, T. (2013). Family vulnerability, family resource management, and family strength of aging family members. Paper presented at $5^{\text {th }}$ International Work and Family Conference, University of Sydney, Australia.

Titus, P. M., Fanslow, A. M., \& Hira, T. K. (1989). Effect of financial management knowledge of household money managers on behaviors and financial outputs. Journal of Vocational Home Economics Education, $7(1), 58-70$.

Xiao, J. J. (1996). Effect of financial income and life cycle stages on financial asset ownership. Journal of Financial Counseling and Planning, 7.

Yohnson. (2004). Peran universitas di Surabaya dalam meningkatkan jumlah keluarga mapan di Surabaya (seri penelitian keuangan keluarga). Jurnal Manajemen \& Kewirausahaan, 6(1),54-71. 